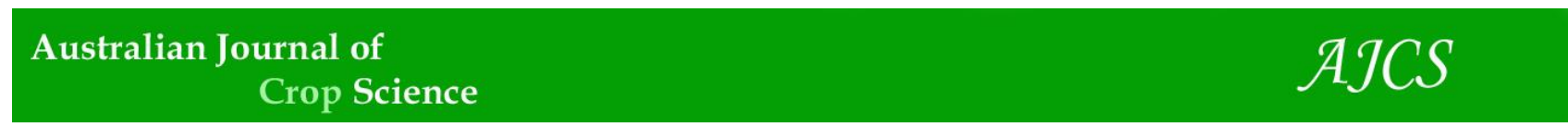

AJCS 12(06):1008-1015 (2018)

ISSN:1835-2707

doi: 10.21475/ajcs.18.12.06.PNE1213

\title{
Influence of different sources of pollen on the chemical composition of date (Phoenix dactylifera L.) cultivar Medjool in México
}

\author{
Ricardo Salomón-Torres ${ }^{1, *}$, Noé Ortiz-Uribe ${ }^{1, *}$, Jesús A. Sol-Uribe ${ }^{1}$, Carlos Villa-Angulo ${ }^{2}$, Rafael Villa- \\ Angulo $^{2}$, Benjamín Valdez-Salas ${ }^{3}$, Conrado García-González ${ }^{4}$, Cesar G. Iñiguez Monroy ${ }^{5}$, Susana \\ Norzagaray-Plasencia ${ }^{5}$
}

\author{
${ }^{1}$ Departamento de Posgrado, Universidad Estatal de Sonora, San Luis Rio Colorado, Sonora, México \\ ${ }^{2}$ Laboratorio de Bioinformatica y Biofotonica, Instituto de Ingeniería, Universidad Autónoma de Baja California, \\ Mexicali, BC, México \\ ${ }^{3}$ Laboratorio de Materiales Avanzados, Instituto de Ingeniería, Universidad Autónoma de Baja California, Mexicali, \\ BC, México \\ ${ }^{4}$ Laboratorio de Procesos Industriales, Instituto de Ingeniería, Universidad Autónoma de Baja California, Mexicali, \\ BC, México \\ ${ }^{5}$ Facultad de Ingeniería, Universidad Autonoma de Baja California, Mexicali, BC, México
}

*Corresponding authors: ricardo.salomon@ues.mx; sinhuet7@hotmail.com

\begin{abstract}
The objective of the present work was to investigate the influence of pollen sources over chemical characteristics of the Medjool date cultivar. The study was conducted under conditions of the Northwest part of Mexico, during the year 2016 cultivation season. The content of nutrients (protein, lipids, fiber and ash), sugars (total, reducing, non-reducing, sucrose, glucose and fructose), and most abundant minerals were evaluated. Three bunches of each of the four selected female palms Medjool cultivar were pollinated with Deglet Noor, Khadrawy, Medjool and Zahidi cultivars, and their fruit were used for the analyses. Results show low concentrations of lipids and ash $(0.68-0.80 \%$ and $2.49-2.82 \%, \mathrm{~g} / 100 \mathrm{~g}$ dry weight basis), while protein and crude fiber were in the range of $2.92-3.35 \%$ and $6.86-7.29 \%$, respectively. In addition, a high content of total sugars (77.78-70.04\%) were found. The predominant mineral was potassium with a range of 794.30 (Khadrawy) - $869.93 \mathrm{mg} / 100 \mathrm{~g}$ dry weight basis (Deglet Noor), followed by magnesium with 136.72 (Medjool) - $150.10 \mathrm{mg} / 100 \mathrm{~g}$ dry weight basis (Khadrawy). An analysis of total phenols revealed that the Khadrawy cultivar had the highest content, with 5.30 (mg GAE/100 g) and the lowest was for Zahidi with 3.82 (mg GAE/100 g). The Khadrawy cultivar had the highest effects on the chemical parameters of the four evaluated treatments. Therefore, pollen source has a significant effect on the chemical properties of the fruit from the Medjool cultivar.
\end{abstract}

Keywords: Chemical composition, Date palm, Medjool, Minerals, Nutritional composition.

Introduction

The date palm (Phoenix dactylifera L.) is one of the oldest crops in the world and has been cultivated for a very long time (Shaaban and Shaaban, 2012). This crop is considered to be the most important in several countries of the Middle East and North Africa, since it plays an essential role in their population diet and socio-economic structure (Ahmed et al., 1995; El-Merghany and El-Daen, 2013; Mohamed et al., 2014; Bouhlali et al., 2017). At present, the highest date cultivation is obtained in countries that are geographically between the $24^{\circ} \mathrm{N}$ and $34^{\circ} \mathrm{N}$ coordinates (Abdeloauhhab and Arias-Jimenez, 1999). These areas are characterized as arid and semi-arid regions where other fruit trees could not survive due to the unfavorable conditions of soil and climate factors. The commercial production requirements of the date palm make this type of soil and climate ideal for cultivation. In addition, its cultivation provides ecological systems stabilization in the recovered desert regions (ElMerghany and El-Daen, 2013).

Dates are rich in several nutrients and are a great source of energy since they contain a high content of carbohydrates $(70-80 \%, g / 100 \mathrm{~g})$, which are mostly in the sugar form. They are low in fat $(0.20-0.50 \%, \mathrm{~g} / 100 \mathrm{~g})$, contain protein $(2.30$ $5.60 \%, \mathrm{~g} / 100 \mathrm{~g})$, dietary fiber $(6.40-11.50 \%, \mathrm{~g} / 100 \mathrm{~g})$, minerals $(0.10-916 \mathrm{mg} / 100 \mathrm{~g})$, and are abundant in potassium and low in sodium. In addition, they contain vitamins such as $A$, B1, B2, B3 and C. They also contain high levels of essential amino-acids and are a good source of flavonoids, carotenoids and phenols (Al-Hooti et al., 1997; Mrabet et al., 2008; Mohamed et al., 2014).

Due to the high nutritional value of the dates, several studies have focused on determining the chemical properties during all stages of growth until maturation, under each country's conditions (Ahmed et al., 1995; Al- 
Hooti et al., 1997). Other studies deal with the identification of the most representative cultivars in each country (Mohamed et al., 2014; Assirey, 2015; Vinita and Punia, 2016; Bouhlali et al., 2017). The chemical composition, sugars, antioxidant activity and mineral content have been reported as their most significant results.

However, no emphasis has been placed on the effect of different sources of pollen in the chemical composition of the date fruit. It is known that pollinators have a direct effect on fruit size, quality and ripening time (Nixon, 1928). Many studies have been developed to evaluate this effect and to select the best source of pollen to obtain the best yields. (Al-Hooti et al., 1997; Mrabet et al., 2008; Borchani et al., 2010; Mohamed et al., 2014; Assirey, 2015; Bouhlali et al., 2017).

Recently, a study was conducted to evaluate the effect of pollinators on recipient females palms of Medjool cultivar in Mexico (Salomon-Torres et al., 2017), concluding that there are significant changes in the quality characteristics of the fruit, opening the possibility that there was also a change in its chemical composition.

According to FAO data, Mexico produced 6,125 tons of date in 2014. Hence, it is ranked as the twenty-eighth largest date producer in the world (FAO, 2015). In addition, in 2016, the Mexican Ministry of Agriculture reported a production of $8,085.57$ tones on a harvested area of 1,183 hectares (SIAP, 2017). Although the commercial cultivation of the Medjool cultivar was introduced in the late 1960s, Mexico has become the second largest producer on the American continent after the United States and the third largest exporter in the world (Krueger, 2015; Salomon-Torres et al., 2017). However in Mexico, few research studies have been carried out related to date cultivars, and there is little knowledge on health and nutritional benefits by the consumption of date fruit.

This study was focused in determining the effect of four different sources of pollen on the chemical composition of the Medjool cultivar. Specifically, we analyzed the content of nutrients, sugars, minerals and phenols in the date fruit under the soil and climate conditions of the northwestern of Mexico.

\section{Results}

\section{Proximate composition of the pulp date}

Significant differences were observed among the four cultivars for the moisture percentage (Table 1). A significantly higher content was observed in the Khadrawy cultivar, being $37.40 \%$ higher than the control, and similar statistically to the Medjool cultivar. The lowest significant moisture content was obtained in the Deglet Noor cultivar with $16.43 \%$ regarding to control treatment. However, it was statistically similar to the Zahidi cultivar.

Our results are low compared to results obtained by two previous studies conducted in India (Vinita and Punia, 2016) and Morocco (Bouhlali et al., 2017); their moisture contents were $85.53 \%$ and $30.82 \%$ for the Medjool cultivar, respectively, compared with our moisture percentage (23.49\%) among four treatments (Table 1). The protein contents are not statistically significant between the four treatments and the control. All percentages of the mean values were lower compared to the control treatment. The average protein content among the four cultivars was $3.14 \%$
(Table 1). The reported results of protein content in (Vinita and Punia, 2016) and (Bouhlali et al., 2017) were $1.88 \%$ and $3.45 \%$ in the Medjool cultivar, respectively. Hence, the date fruit yields a low amount of protein (g/100 g). A low fat content was found among the four cultivars (Table 1). The highest average $(7.50 \%)$ was for the Khadrawy cultivar and the lowest for the Deglet Noor cultivar $(-8.82 \%)$, compared to the control treatment. The average fat content shown in this study is $0.75 \%$ among four sources of pollen, while lower percentages $(0.17 \%$ and $0.31 \%)$ were obtained by (Vinita and Punia, 2016; Bouhlali et al., 2017), respectively. The influence of various pollen sources does not have a significant effect on the fruit crude fiber (Table 1). It was found that the highest average value was $4.66 \%$ for Zahidi cultivar and the lowest average value was for the Deglet Noor cultivar with $-1.31 \%$, with respect to control treatment. The study performed in India (Vinita and Punia, 2016) reported $1.96 \%$, while our average crude fiber among four treatments was $7.07 \%$. Significant differences were observed for the ash content among the four cultivars (Table 1). The higher content was observed in the Khadrawy cultivar, being a $16.31 \%$ higher than the control treatment. The lowest hash content was obtained in the Deglet Noor cultivar with a $5.22 \%$ regarding to control treatment. However, it was statistically similar that the rest of the treatments. The results reported in India (Vinita and Punia, 2016) and Morocco (Bouhlali et al., 2017) were $3.02 \%$ and $2.30 \%$, respectively, while our average ash percentage was $2.62 \%$ (Table 1). The source of pollen does not have a significant effect on the determination of total soluble solids, insoluble solids, total acidity and $\mathrm{pH}$. The percentage differences were smaller with respect to the control treatment, with the exception of the total acidity (Table 2 ).

\section{Content analysis of sugars}

The main characteristic of the date fruit is the high sugar content, making it a good source of energy for the human body. With only $100 \mathrm{~g}$ it can offer an average of $314 \mathrm{Kcal}$. (Vinita and Punia, 2016). Carbohydrates in dates can be identified primarily as reducing and non-reducing sugars. Reduced sugars are present in the form of glucose, fructose, mannose and maltose. Non-reducing agents are found essentially as sucrose and in small amounts of polysaccharides such as cellulose and starch (Al-Shahib and Marshall, 2003; Vinita and Punia, 2016).

The effect of the four treatments on the average total sugar content was statistically significant (Table 3 ). The Khadrawy cultivar was the highest (8.51\%) and the Medjool cultivar was the lowest $(-1.6 \%)$, with respect to control treatment. The reducing sugars ranged from $-4.43 \%$ to 9.76\% for Medjool and Khadrawy cultivars respectively, compared to control treatment. All the values were statistically significant among them (Table 3). The nonreducing sugars ranged from $-12.27 \%$ to $25.60 \%$, for Khadrawy and Medjool cultivars respectively, against the control treatment. All the values were not statistically significant among them (Table 3). The Khadrawy cultivar exhibited the lowest percentage of sucrose $(-12.44 \%)$ and Medjool cultivar the highest $(25.52 \%)$, versus the control treatment. However, only the first of them was statistically significant, compared to other treatments (Table 3). The Medjool cultivar has the lowest percentage of glucose ($3.13 \%)$ and Khadrawy cultivar the highest (10.58\%), compared 
Table 1. Proximate composition of Medjool dates, obtained from pollination using pollen from the Deglet Noor, Khadrawy, Medjool and Zahidi cultivars.

\begin{tabular}{|c|c|c|c|c|c|}
\hline \multirow{2}{*}{ Cultivar } & \multirow{2}{*}{ Moisture (\%) } & \multicolumn{4}{|c|}{ Nutrients (\%, g/100 g, dry weight) } \\
\hline & & Crude protein & Lipid & Crude fiber & Ash \\
\hline Deglet Noor & $19.75 \pm 0.96 b$ & $3.30 \pm 0.23 a$ & $0.68 \pm 0.07 a$ & $6.86 \pm 1.18 a$ & $2.49 \pm 0.13 b$ \\
\hline Khadrawy & $27.38 \pm 0.58 a$ & $3.35 \pm 0.30 a$ & $0.80 \pm 0.12 b$ & $6.98 \pm 0.92 a$ & $2.82 \pm 0.11 c$ \\
\hline Medjool & $26.32 \pm 0.86 a$ & $2.92 \pm 0.09 a$ & $0.74 \pm 0.05 b$ & $7.15 \pm 0.65 a$ & $2.59 \pm 0.07 b$ \\
\hline Zahidi & $20.51 \pm 0.76 b$ & $3.00 \pm 0.01 a$ & $0.78 \pm 0.11 b$ & $7.29 \pm 1.27 a$ & $2.58 \pm 0.13 b$ \\
\hline Control & $17.14 \pm 0.80 b$ & $3.47 \pm 0.11 a$ & $0.74 \pm 0.19 b$ & $6.95 \pm 0.91 a$ & $2.36 \pm 0.03 a$ \\
\hline
\end{tabular}

values are mean \pm SD of 45 samples with 3 independent determinations. Means followed by same letter(s) in a column do not differ significantly at 0.05 probability level.

Table 2. Content of total soluble solids, insoluble solids, total acidity and pH of Medjool dates, pollinated with the Deglet Noor, Khadrawy, Medjool and Zahidi cultivars (\%, g/100 g dry weight).

\begin{tabular}{lllll}
\hline Cultivar & Total soluble solids & Insoluble solids & Total acidity & $\mathrm{pH}$ \\
\hline Deglet Noor & $66.04 \pm 6.92 \mathrm{ab}$ & $13.73 \pm 3.64 \mathrm{a}$ & $0.08 \pm 0.007 \mathrm{a}$ & $6.83 \pm 0.17 \mathrm{a}$ \\
Khadrawy & $64.96 \pm 6.96 \mathrm{~b}$ & $15.15 \pm 4.37 \mathrm{a}$ & $0.08 \pm 0.003 \mathrm{a}$ & $6.82 \pm 0.28 \mathrm{a}$ \\
Medjool & $67.50 \pm 8.36 \mathrm{ab}$ & $17.05 \pm 2.61 \mathrm{a}$ & $0.08 \pm 0.006 \mathrm{a}$ & $6.84 \pm 0.29 \mathrm{a}$ \\
Zahidi & $66.45 \pm 4.97 \mathrm{ab}$ & $16.88 \pm 2.58 \mathrm{a}$ & $0.07 \pm 0.002 \mathrm{a}$ & $6.93 \pm 0.22 \mathrm{a}$ \\
Control & $74.54 \pm 7.31 \mathrm{a}$ & $18.29 \pm 2.31 \mathrm{a}$ & $0.07 \pm 0.001 \mathrm{a}$ & $6.86 \pm 0.37 \mathrm{a}$ \\
\hline
\end{tabular}

Values are mean \pm SD of 45 samples with 3 independent determinations. Means followed by same letter(s) in a column do not differ significantly at 0.05 probability level.

Table 3. Sugar content and energy of Medjool dates, pollinated with the Deglet Noor, Khadrawy, Medjool and Zahidi cultivars (g/100 g dry weight).

\begin{tabular}{llllllll}
\hline Cultivar & Total sugars & $\begin{array}{l}\text { Reducing } \\
\text { sugars }\end{array}$ & $\begin{array}{l}\text { Non- } \\
\text { reducing } \\
\text { sugars }\end{array}$ & Sucrose & Glucose & Fructose & $\begin{array}{l}\text { Energetic } \\
\text { value } \\
(\mathrm{kcal} / 100 \mathrm{~g})\end{array}$ \\
\hline Deglet Noor & $76.71 \pm 0.92 \mathrm{ab}$ & $71.03 \pm 1.46 \mathrm{~b}$ & $5.68 \pm 1.40 \mathrm{a}$ & $5.40 \pm 1.33 \mathrm{ab}$ & $38.50 \pm 1.67 \mathrm{a}$ & $32.53 \pm 0.52 \mathrm{~b}$ & $336.52 \pm 6.1 \mathrm{ab}$ \\
Khadrawy & $77.78 \pm 1.15 \mathrm{a}$ & $73.38 \pm 1.20 \mathrm{a}$ & $4.40 \pm 0.10 \mathrm{a}$ & $4.18 \pm 0.10 \mathrm{~b}$ & $38.75 \pm 1.48 \mathrm{a}$ & $35.08 \pm 1.02 \mathrm{a}$ & $342.15 \pm 7.85 \mathrm{a}$ \\
Medjool & $70.04 \pm 1.43 \mathrm{c}$ & $63.41 \pm 0.66 \mathrm{~d}$ & $6.64 \pm 1.55 \mathrm{a}$ & $6.31 \pm 1.47 \mathrm{a}$ & $33.60 \pm 1.64 \mathrm{c}$ & $29.80 \pm 1.10 \mathrm{c}$ & $308.01 \pm 8.20 \mathrm{c}$ \\
Zahidi & $75.62 \pm 0.48 \mathrm{~b}$ & $70.42 \pm 0.85 \mathrm{~b}$ & $5.20 \pm 0.84 \mathrm{a}$ & $4.94 \pm 0.80 \mathrm{ab}$ & $36.92 \pm 2.01 \mathrm{ab}$ & $33.49 \pm 1.18 \mathrm{~b}$ & $331.99 \pm 3.00 \mathrm{~b}$ \\
Control & $71.16 \pm 1.09 \mathrm{c}$ & $66.22 \pm 1.26 \mathrm{c}$ & $4.94 \pm 1.58 \mathrm{a}$ & $4.70 \pm 1.50 \mathrm{ab}$ & $34.65 \pm 0.22 \mathrm{bc}$ & $31.56 \pm 1.05 \mathrm{bc}$ & $314.16 \pm 6.92 \mathrm{c}$ \\
\hline
\end{tabular}

Values are mean \pm SD of 45 samples with 3 independent determinations. Means followed by same letter(s) in a column do not differ significantly at 0.05 probability level.

Table 4. Total macrominerals content for four treatments and control for a recipient female Medjool cultivar (mg/100g, dry weight).

\begin{tabular}{lllllll}
\hline \multirow{2}{*}{ Cultivar } & Minerals & & & & \\
\cline { 2 - 6 } & Potassium & Magnesium & Calcium & Phosphorus & Sulfur & Sodium \\
\hline Deglet Noor & $869.93 \pm 19.6 \mathrm{a}$ & $139.30 \pm 1.01 \mathrm{c}$ & $106.76 \pm 0.4 \mathrm{c}$ & $139.43 \pm 2.5 \mathrm{~b}$ & $111.00 \pm 1.3 \mathrm{~b}$ & $27.40 \pm 0.6 \mathrm{~d}$ \\
Khadrawy & $794.30 \pm 7.9 \mathrm{c}$ & $150.10 \pm 2.03 \mathrm{a}$ & $131.73 \pm 1.1 \mathrm{a}$ & $135.41 \pm 1.1 \mathrm{c}$ & $184.33 \pm 1.5 \mathrm{a}$ & $44.73 \pm 0.5 \mathrm{a}$ \\
Medjool & $855.98 \pm 2.2 \mathrm{~b}$ & $136.72 \pm 1.01 \mathrm{~d}$ & $131.4 \pm 0.4 \mathrm{a}$ & $143.37 \pm 2.6 \mathrm{a}$ & $147.34 \pm 1.4 \mathrm{ab}$ & $34.63 \pm 0.2 \mathrm{~b}$ \\
Zahidi & $856.49 \pm 11.9 \mathrm{~b}$ & $145.75 \pm 1.1 \mathrm{~b}$ & $124.3 \pm 0.8 \mathrm{~b}$ & $105.4 \pm 1.6 \mathrm{~d}$ & $108.33 \pm 2.1 \mathrm{~b}$ & $27.03 \pm 0.5 \mathrm{~d}$ \\
Control & $858.28 \pm 22.3 \mathrm{~b}$ & $132.10 \pm 1.40 \mathrm{e}$ & $105.23 \pm 1.5 \mathrm{~d}$ & $145.70 \pm 1.8 \mathrm{a}$ & $110.33 \pm 1.4 \mathrm{~b}$ & $28.90 \pm 0.4 \mathrm{c}$ \\
\hline
\end{tabular}

Values are mean \pm SD of three independent determinations. Means followed by same letter(s) in a column do not differ significantly at 0.05 probability level.

Table 5. Total microminerals content for four treatments and control for a recipient female Medjool cultivar (mg/100g, dry weight).

\begin{tabular}{llllllll}
\hline \multirow{2}{*}{ Cultivar } & Minerals & \multicolumn{7}{l}{} \\
\cline { 2 - 7 } & Silicon & Selenium & Copper & Iron & Strontium & Manganese & Zinc \\
\hline Deglet Noor & $23.033 \pm 0.4 \mathrm{a}$ & $4.975 \pm 1.3 \mathrm{a}$ & $1.141 \pm 0.356 \mathrm{a}$ & $0.763 \pm 0.010 \mathrm{a}$ & $0.428 \pm 0.010 \mathrm{~b}$ & $0.466 \pm 0.02 \mathrm{~b}$ & $0.614 \pm 0.05 \mathrm{a}$ \\
Khadrawi & $13.633 \pm 0.2 \mathrm{~b}$ & $5.221 \pm 0.3 \mathrm{a}$ & $0.862 \pm 0.333 \mathrm{a}$ & $0.348 \pm 0.003 \mathrm{~b}$ & $0.400 \pm 0.015 \mathrm{c}$ & $0.436 \pm 0.01 \mathrm{c}$ & $0.205 \pm 0.02 \mathrm{c}$ \\
Medjool & $2.783 \pm 0.1 \mathrm{~d}$ & $5.468 \pm 1.4 \mathrm{a}$ & $0.445 \pm 0.473 \mathrm{~b}$ & $0.123 \pm 0.007 \mathrm{~d}$ & $0.220 \pm 0.010 \mathrm{e}$ & $0.175 \pm 0.04 \mathrm{e}$ & $0.084 \pm 0.01 \mathrm{~d}$ \\
Zahidi & $8.783 \pm 0.1 \mathrm{c}$ & $5.256 \pm 0.3 \mathrm{a}$ & $1.133 \pm 0.306 \mathrm{a}$ & $0.155 \pm 0.008 \mathrm{c}$ & $0.566 \pm 0.012 \mathrm{a}$ & $0.419 \pm 0.02 \mathrm{~d}$ & $0.100 \pm 0.02 \mathrm{~d}$ \\
Control & $0.766 \pm 0.1 \mathrm{e}$ & $6.052 \pm 1.3 \mathrm{a}$ & $0.993 \pm 0.528 \mathrm{a}$ & $0.129 \pm 0.006 \mathrm{~d}$ & $0.330 \pm 0.013 \mathrm{~d}$ & $0.727 \pm 0.03 \mathrm{a}$ & $0.340 \pm 0.02 \mathrm{~b}$ \\
\hline \multicolumn{7}{l}{ Values are mean \pm SD of three independent determinations. Means followed by same letter(s) in a column do not differ significantly at 0.05 probability level. }
\end{tabular}

Table 6. Total phenols content for four pollination treatments and control for a recipient female Medjool cultivar (mg GAE / g, dry weight).

\begin{tabular}{llllll}
\hline Cultivar & Deglet Noor & Khadrawy & Medjool & Zahidi & Control \\
\hline Total phenols & $5.08 \pm 0.19 \mathrm{c}$ & $5.30 \pm 0.22 \mathrm{c}$ & $5.02 \pm 0.20 \mathrm{c}$ & $3.82 \pm 0.38 \mathrm{a}$ & $4.54 \pm 0.21 \mathrm{~b}$ \\
\hline
\end{tabular}

Values are mean \pm SD of 45 samples with 3 independent determinations. Means followed by same letter(s) in a horizontal row do not differ significantly at 0.05 probability level. 
to control treatment. The glucose content showed statistical differences among the treatments (Table 3). The Medjool cultivar had the lowest amount of fructose $(-5.91 \%)$ and the Khadrawy cultivar the highest $(10.03 \%)$, with respect to control treatment. The fructose content was statistically significant among treatments (Table 3).

The study developed in Morocco (Bouhlali et al., 2017) reported 33.96 and $37.79 \mathrm{~g} / 100 \mathrm{~g}$ for glucose and fructose, respectively for the Medjool cultivar, while the average of our four treatments was 36.94 and $32.72 \mathrm{~g} / 100 \mathrm{~g}$ respectively for the same parameters. Also the study from India (Vinita and Punia, 2016) reported 67.49, 61.31 and $6.18 \mathrm{~g} / 100 \mathrm{~g}$ for total sugars, reducing and non-reducing sugars, respectively for the Medjool cultivar, while the average of our four treatments was 75.03, 69.56 and 5.48 $\mathrm{g} / 100 \mathrm{~g}$ respectively for the same variables evaluated. Higher values are observed in our study for glucose, total sugars and reducing sugars, but lower values for fructose and non-reducing sugars, compared with the data reported in Morocco and India. The energetic values of the treatments analyzed were statistically significant among treatments (Table 3). Medjool cultivar has the lowest amount of energetic value $(-2.00 \%)$ and Khadrawy cultivar the highest (8.18\%), compared to control treatment.

\section{Content evaluation of macrominerals}

Significant differences were observed between the treatments for the macrominerals. The potassium concentration was the highest, and was followed in descending order by magnesium, calcium, phosphorus, sulfur and sodium (Table 4). The Deglet Noor cultivar had the highest percentage with $1.34 \%$ and the Medjool cultivar had the smallest with $-0.27 \%$, with respect to the potassium content of the control treatment. The average of potassium content among the four cultivars $(844.17 \mathrm{mg} / 100 \mathrm{~g}$, dry weight basis) was very similar to that reported in Morocco ( $849.58 \mathrm{mg} / 100 \mathrm{~g}$ ) (Bouhlali et al., 2017), while the reported in India (Vinita and Punia, 2016) was $713 \mathrm{mg} / 100 \mathrm{~g}$. However, higher values were obtained for the rest of macrominerals measured in this study, against both studies. The Khadrawy cultivar had the highest percentage with $11.99 \%$ and the Medjool cultivar had the smallest with $3.38 \%$, compared with the magnesium content of the control treatment. An average of $142.96 \mathrm{mg} / 100 \mathrm{~g}$ was obtained from the four treatments, while in previous studies (Vinita and Punia, 2016; Bouhlali et al., 2017) an average of 67.78 and 53.66 $\mathrm{mg} / 100 \mathrm{~g}$ were respectively obtained. The Khadrawy cultivar had the highest percentage with $20.12 \%$ and the Deglet Noor cultivar had the smallest with $1.43 \%$, compared with the calcium content of the control treatment. The average of calcium content of four cultivars was $123.54 \mathrm{mg} / 100 \mathrm{~g}$ while in previous studies (Vinita and Punia, 2016; Bouhlali et al., 2017) an average of 54.2 and $70.33 \mathrm{mg} / 100 \mathrm{~g}$ were obtained, respectively. All percentages of the means were lower versus the phosphorus content of the control treatment. The obtained average concentration of phosphorus among four sources of pollen was 130.90 $\mathrm{mg} / 100 \mathrm{~g}$, while in India (Vinita and Punia, 2016) was found $52.66 \mathrm{mg} / 100 \mathrm{~g}$. The Khadrawy cultivar had the highest percentage with $40.15 \%$ and the Zahidi cultivar had the smallest with $-1.85 \%$, against the sulfur content of the control treatment. The obtained average content among treatments of sulfur was $137.75 \mathrm{mg} / 100 \mathrm{~g}$. This parameter has not been reported in other studies for the Medjool cultivar. The Khadrawy cultivar had the highest percentage with $35.39 \%$ and the Zahidi cultivar had the smallest with $6.92 \%$, versus the sulfur content of the control treatment. The obtained average concentration of sodium for the four sources of pollen was $33.44 \mathrm{mg} / 100 \mathrm{~g}$, while $11.21 \mathrm{mg} / 100 \mathrm{~g}$ was obtained in Morocco (Bouhlali et al., 2017). These observed variations could be attributed to factors involved in the cultivation, such as the level of soil fertility, the amount of applied fertilizers to the palms, as well as the agro-climatic conditions of each country (Yousif et al., 1982). Minerals are important for the formation and proper functioning of bones, teeth, soft tissues, hemoglobin, muscle and nerve cells (Al-Farsi and Lee, 2008). The combination of high potassium and low sodium in the dates can be used to control or prevent hypertension. Similarly, it decreases cardiovascular morbidity, renal disease and cardiovascular diseases (Aaron et al., 2013). Consumption of calcium and magnesium maintains adequate body growth, facilitates bone mobility and supports vascular function (Bouhlali et al., 2017). The consumption of $100 \mathrm{~g}$ of dates provides approximately $15 \%$ of recommended potassium, magnesium, copper and selenium daily diet, while dates iron, phosphorus, manganese and calcium concentrations provide $7 \%$ of recommended daily diet (Al-Farsi and Lee, 2008).

\section{Content evaluation of microminerals}

Significant differences were observed between the treatments with the microminerals. The silicon content was the highest, and was followed in descending order by selenium, copper, iron, strontium, manganese and zinc (Table 5). The Deglet Noor cultivar had the highest percentage with $96.67 \%$ and the Medjool cultivar had the smallest with $72.48 \%$, with respect to the silicon content of the control treatment. The average content of silicon among the four cultivars was $12.05 \mathrm{mg} / 100 \mathrm{~g}$, while in the control cultivar was $0.766 \mathrm{mg} / 100 \mathrm{~g}$. The results of all treatments were minor, compared to selenium content of the control treatment. The average of selenium concentration among the treatments was $5.23 \mathrm{mg} / 100 \mathrm{~g}$, while the average for the control treatment was $6.05 \mathrm{mg} / 100 \mathrm{~g}$. The Deglet Noor cultivar had the highest percentage with $12.97 \%$ and the Medjool cultivar had the smallest with $-123.15 \%$, against the copper content of the control treatment. Copper has an average among four pollen sources of $0.89 \mathrm{mg} / 100 \mathrm{~g}$, while the control has an average of $0.99 \mathrm{mg} / 100 \mathrm{~g}$. The study conducted in Morocco (Bouhlali et al., 2017) reports an average of $0.344 \mathrm{mg} / 100 \mathrm{~g}$ for copper content in the Medjool cultivar. The Deglet Noor cultivar had the highest percentage with $83.09 \%$ and the Medjool cultivar had the smallest with $-4.88 \%$, against the iron content of the control treatment. Iron provides an average of $0.34 \mathrm{mg} / 100 \mathrm{~g}$ among the four treatments, while the control provides a $0.129 \mathrm{mg} / 100 \mathrm{~g}$. Previous studies reported $1.14 \mathrm{mg} / 100 \mathrm{~g}$ and $1.91 \mathrm{mg} / 100 \mathrm{~g}$ for Morocco and India respectively (Vinita and Punia, 2016; Bouhlali et al., 2017). The Zahidi cultivar had the highest percentage with $41.70 \%$ and the Medjool cultivar had the smallest with $-50.00 \%$, compared the strontium content of the control treatment. An average of $0.40 \mathrm{mg} / 100 \mathrm{~g}$ for strontium content was obtained, while 
a $0.33 \mathrm{mg} / 100 \mathrm{~g}$ was obtained for the control. The results of all treatments were minor, compared to manganese content of the control treatment. An average of $0.37 \mathrm{mg} / 100 \mathrm{~g}$ in manganese content was obtained for the four treatments and control was $0.72 \mathrm{mg} / 100 \mathrm{~g}$. The study realized in Morocco reported manganese content of $0.32 \mathrm{mg} / 100 \mathrm{~g}$. The Deglet Noor cultivar had the highest percentage with 44.63\% and the Medjool cultivar had the smallest with $304.76 \%$, regarding the zinc content of the control treatment. An average zinc concentration of $0.25 \mathrm{mg} / 100 \mathrm{~g}$ among the four cultivars and $0.34 \mathrm{mg} / 100 \mathrm{~g}$ for the control treatment was obtained. The studies developed in India and Morocco reported a zinc concentration average of 1.42 $\mathrm{mg} / 100 \mathrm{~g}$ and $0.37 \mathrm{mg} / 100 \mathrm{~g}$, respectively (Vinita and Punia, 2016; Bouhlali et al., 2017). No studies were found reporting the contents of selenium, and strontium.

Microminerals, in small quantities, are required elements in our body. Copper, iron, manganese, and zinc play an essential role in many processes and metabolic pathways. It is also estimated that magnesium binds only transiently on enzymes. In addition, zinc, iron and manganese are the three metals most commonly used by enzymes and copper is the seventh most used (Andreini et al., 2008).

\section{Content analysis of total phenols}

Significant differences were observed among the four treatments for the total phenols content (Table 6). A significantly higher content was observed in the Khadrawy cultivar, being $14.34 \%$ higher than the control, and similar statistically to the Medjool and Deglet Noor cultivars. The lowest significant total phenols content was obtained in the Zahidi cultivar with a $-18.85 \%$ regarding to control treatment. An average of $4.80 \mathrm{mg} \mathrm{GAE} / \mathrm{g}$ in total phenol content was the influence of the four sources of pollen, whereas the control treatment was $4.54 \mathrm{mg} \mathrm{GAE} / \mathrm{g}$. The phenol content determined in this study was higher than that reported by the study in Morocco with $3.98 \mathrm{mg} \mathrm{GAE} / \mathrm{g}$ for the Medjool cultivar (Bouhlali et al., 2017). The average phenols content expressed in this experiment is higher than that reported in raisins ( $1.94 \mathrm{mg} \mathrm{CE} / \mathrm{g})$, in figs $(2.56 \mathrm{mg} \mathrm{CE} / \mathrm{g}$ ) and in apricot (3.33 mg CE/g). However, it is lower in plums (5.51 mg CE/g) (Vinson et al., 2005; Bouhlali et al., 2017).

\section{Discussion}

The treatments used in this study have a direct effect on the chemical composition of the Medjool cultivar. However, some parameters such as total soluble solids, insoluble solids, total acidity, $\mathrm{pH}$, protein, crude fiber, non-reducing sugars, and selenium showed no significant differences. The difference among our data versus the results obtained in the two previous studies may be explained by the agro-climatic and environmental conditions among the countries (Assirey, 2015).

The Deglet Noor cultivar induced the highest potassium content among the four analyzed pollen sources. This result is in agreement with results obtained by Borchani et al., (2010), who determined the chemical properties of 11 different cultivars. In the Borchani study, the highest potassium content was found also in Deglet Noor cultivar. In addition, in the Borchani study, Deglet Noor cultivar also presented the highest content of silicon, iron, manganese and zinc. Pollen from the Khadrawy cultivar induced the highest average percentages of moisture, crude protein, lipids, ash, total sugars, reducing sugars, glucose, fructose, magnesium, calcium, sulfur, sodium, copper, total phenols and energetic value. It also had the lowest potassium content. However, in the proximal analysis, it had values higher than those reported by Ghnimi et al., (2017), with exception of fiber content. The Medjool treatment, reported the highest content of non-reducing sugars, sucrose, calcium, phosphorus and selenium, but the lowest in total sugars, reducing sugars, glucose, fructose, crude protein, magnesium, silicon, iron, strontium, manganese, zinc and energetic value, while average values were obtained in the rest of the parameters. However, comparing the obtained results for cultivar Medjool against the results reported by Amadou (2016), in proximal and macromineral analysis, our results show higher values, except for the parameter of total sugars. Zahidi cultivar has the highest content in crude fiber and strontium, but the lowest content in total phenols, phosphorus, sulfur, sodium and copper. In the rest of evaluated parameters it maintained average percentages. However, all results obtained in the proximal analysis of Zahidi cultivar were higher than reported by (Ghnimi et al., 2017).

All values for the proximate composition, solids, sugars, micro and macrominerals, obtained by the control treatment were below the average value shown by the four cultivars excepting crude protein, phosphorus, selenium, manganese and phenols.

Finally, when the date fruit was cut in half to extract its seed, it was evident that the fruit pollinated with the Khadrawy cultivar shows a more intense aroma than the rest of the cultivars. In order to verify this evidence, a simple olfactory one-sense test was performed, where the referees validated that the Khadrawy treatment had the higher aromatic perception against the rest of the treatments. Due to the result of this test, a phenol content analysis was performed (Table 6) where the Khadrawy cultivar was determined to have the highest total phenol content (5.30 $\mathrm{mg} \mathrm{GAE} / \mathrm{g}$ ), which corroborates the obtained result of the aromatic intensity test.

\section{Materials and methods}

\section{Characterization of the experimental area}

The experiment was conducted on an orchard of 15 ha with organic certification, located in "Rancho La Vaca", under the geographical coordinates: latitude $32^{\circ} 23^{\prime} 5^{\prime \prime} \mathrm{N}$, longitude $114^{\circ} 53^{\prime} 55^{\prime \prime} \mathrm{W}$ and average altitude of $45 \mathrm{~m}$, located in the San Luis Rio Colorado Valley of Northwest Mexico. The soil is classified as alluvial from dry bed of Colorado River. The irrigation technique is by flooding, distributed in six cycles per year, with an irrigation sheet of $15 \mathrm{~cm}$, and the field is organically fertilized, with a formulation of macro and micronutrients, aminoacids, humic acids, rock dust, bone meal, phosphoric rock and calcium polisulfide developed for date palm by the company Fertiorganicos SuperCosecha ${ }^{\circledR}$. According to statistics from the National Mexican Meteorological System, for the northwestern area, in 2016 the annual rainfall was $84.80 \mathrm{~mm}$. The annual average mean and the maximum and minimum average mean of air 
temperatures were $22.70{ }^{\circ} \mathrm{C}, 32.00{ }^{\circ} \mathrm{C}$, and $13.50{ }^{\circ} \mathrm{C}$, respectively. (http://smn.conagua.gob.mx/es).

\section{Plant materials and pollination}

Male inflorescences were collected once the spathes were naturally broken; they were then transported to a drying area, the inflorescences were hung separately during a 3-day period and the pollen was collected daily on a paper bed (Abdeloauhhab and Arias-Jimenez, 1999). The pollen was stored at $4{ }^{\circ} \mathrm{C}$ until pollination time. Four female palms were selected randomly and used as recipients. These plants were derived from a Medjool cultivar of 13 years of age and vigor. Palms were planted with an $8 \times 8 \mathrm{~m}$ distance between rows and plants. Pollen preparation, pollination method and bunch treatment in this study was performed according to Salomon-Torres et al., (2017).

\section{Treatments and experimental design}

The experiment employed was the randomized complete block design, $4 \times 4$ with three replications. Four elite date palm males of Deglet Noor, Medjool, Khadrawy, and Zahidi cultivars, of 15 years of age and vigor (creoles), were used as the source of pollen for the pollination of the Medjool cultivar. During the 2016 season at the harvest time (tamr stage), full ripeness fruit samples were randomly selected for each treatment. From an additional palm, fruits were taken which served as control for comparisons. This additional palm was pollinated with the regular farmer treatment. The regular farmer treatment consists of mixing pollen form different unknown sources. The samples were rinsed, the seed removed and the pulp stored at $-20{ }^{\circ} \mathrm{C}$ until extraction and analysis.

\section{Statistical analysis}

The collected data were submitted to analysis of variance, in a balanced design using one-way ANOVA. The means of the cultivars were compared by a multiple comparison of means by the least significant differences (LSD) test, at a significance level of $5 \%$ (Steel and Torrie, 1980). The statistical analysis was calculated using version 3.4 .2 of Statistical Software R (Kabacoff, 2011; R Core Team, 2015). Finally, the results were expressed as mean values \pm standard deviation of the three separate determinations by sample.

\section{Proximate analysis}

For the proximal analysis, nine samples from each treatment and three replicates from each sample were used. Approximately $5 \mathrm{~g}$ of weight from each sample was incubated at $105^{\circ} \mathrm{C}$ during $24 \mathrm{~h}$ to determine the moisture content of each variety. Furthermore, the samples were incinerated at $550{ }^{\circ} \mathrm{C}$ for $8 \mathrm{~h}$ and the ash percentage was calculated by weight differences (AOAC, 2000). The crude protein was passed through a chemical digestion process (Kjeldahl method) to determine total nitrogen. Subsequently it was converted to protein percentage (AOAC, 2000) expressed with the general factor of 6.25 (Hall, 1996). Total lipids were determined according to the method of Folch et al., (1957). All the elements were expressed in $\mathrm{g} / 100 \mathrm{~g}$, dry weight basis. Additionally, insoluble solids, total soluble solids, total acidity and $\mathrm{pH}$ were determined. Total insoluble and soluble solids were determined using ${ }^{\circ}$ Brix (Ruck, 1969). The total acidity was determined titrating against $0.1 \mathrm{~N}$ $\mathrm{NaOH}$ and was expressed as percentage malic acid. The $\mathrm{pH}$ was taken from a homogeneous sample at $20^{\circ} \mathrm{C}$ using a MP $744 \mathrm{pH}$ meter.

\section{Sugars determination}

For the analysis of sugars, nine samples from each treatment and three replicates from each sample were used. Reducing, non-reducing, total sugars and sucrose were determined using the Lane and Eynon volumetric method (Oberoi and Sogi, 2017). Glucose and fructose were determined using an enzymatic glucose analyzer (Galant et al., 2015).

\section{Minerals determination}

For the analysis of minerals, from each treatment, one sample and three replicates from each sample were used. The mineral content was determined using standard methods (AOAC, 2000). About $2 \mathrm{~g}$ of pulp from each sample was converted to ash at $550{ }^{\circ} \mathrm{C}$ during $24 \mathrm{~h}$. Then one $\mathrm{g}$ of ash was dissolved in $5 \mathrm{ml}$ of analytical grade hydrochloric acid $(20 \%)$ and the solution was transferred to a $50 \mathrm{ml}$ volumetric flask. The final volume was completed using deionized water. The total minerals were determined using an atomic absorption spectrophotometer (model $4200 \mathrm{MP}$ AES, Agilent Technologies) and were expressed in $\mathrm{mg} / 100 \mathrm{~g}$ dry weight basis.

\section{Total phenols determination}

For the total phenols determination, nine samples from each treatment and three replicates from each sample were used. Total phenols were determined using the Folin-Ciocalteu method described by Alexaindre-Tudo et al. (2017). The results were expressed as milligrams of equivalent gallic acid per 100g dry weight (mg GAE/100g DW).

\section{Energy value determination}

The energetic value for each treatment was calculated using the content of crude protein, fat and carbohydrates (total sugars), by the formula described by Crisan and Sands, (1978): Energy value $(\mathrm{kcal} / 100 \mathrm{~g})=(2.62 \times \%$ protein $)+(8.37$ $\times \%$ fat $)+(4.2 \times \%$ carbohydrate $)$.

\section{Sensory evaluation}

A group of 5 experts in date cultivation, who work for the company "Rancho La Vaca", served as referee in a performed simple olfactory one-sense test (Pratt, 1994). The test consisted, for each of the four treatments, in determining the intensity of the aromatic property from the date fruit. To evaluate this property, an aroma intensity scale from 1 to 4 was stablished, where 1 is non-perceptible, 2 is poorly perceptible, 3 is perceptible and 4 is highly perceptible. For each treatment to be evaluated, prior to the olfactory evaluation, three half of date fruits without seed were deposited inside a plastic bag by a period of four hours. Each referee smelled/evaluated three date samples of each 
cultivar. This evaluation was performed in a room free of aromas with an inside temperature of $24^{\circ} \mathrm{C}$.

\section{Conclusions}

The Khadrawy cultivar presented the highest effects on the chemical properties of the four evaluated treatments, producing significant effects on the fruit of the Medjool cultivar. The high sugar content obtained by the Khadrawy treatment suggests that it could be taken as a possible substitute for sugar. Also the aroma induced by this treatment could add value to wines, oils, cakes and other products containing date. The knowledge of dates nutritional variation as affected by the pollen source, will allow genetic improvement and to develop products with specific nutritional characteristics.

\section{Acknowledgments}

We are grateful to Corporative RUVA, for funding and the use of their facilities in the realization of this study. To Rafael Quirarte-Gutierrez and Roberto Torres-Yescas from Rancho "La Vaca" for their support and advice. This research was funded in part by PRODEP (511-6/17-7559).

\section{References}

Aaron KJ, Sanders PW, Hall JE, Al E, Pasquale PD, Zhu D (2013) Role of dietary salt and potassium intake in cardiovascular health and disease: A review of the evidence. Mayo Clin Proc. 88: 987-995.

Abdelouauhhab Z, Arias-Jimenez EJ (1999) Date palm cultivation, 1st edn. FAO, Rome.

Ahmed IA, Ahmed AWK, Robinson RK (1995) Chemical composition of date varieties as influenced by the stage of ripening. Food Chem. 54: 305-309.

Aleixandre-Tudo JL, Buica A, Nieuwoudt $\mathrm{H}$, Aleixandre JL duToit W (2017) Spectrophotometric analysis of phenolic compounds in grapes and wines. J Agric Food Chem. 65: 4009-4026.

Al-Farsi MA, Lee CY (2008) Nutritional and functional properties of dates: a review. Crit Rev Food Sci Nutr. 48: 877-887.

Al-Hooti S, Sidhu JS, Qabazard H (1997) Physicochemical characteristics of five date fruit cultivars grown in the United Arab Emirates. Plant Foods Hum Nutr. 50: 101-113.

Al-Shahib W, Marshall R (2003) The fruit of the date palm: its possible use as the best food for the future. Int J Food Sci Nutr. 54: 247-259.

Amadou I (2016) Date fruits: Nutritional composition of dates (Balanites aegyptiaca Delile and Phoenix dactylifera L.). In: Victor RP, Monique SJS (eds) Nutritional composition of Fruit cultivars, 1st edn. Academic Press, London.

Andreini C, Bertini I, Cavallaro G, Holliday GL, Thornton JM (2008) Metal ions in biological catalysis: from enzyme databases to general principles. J Biol Inorg Chem. 13: 1205-1218.

AOAC (2000) Official methods of analysis of association of official agriculture chemist. Association of analytical chemist, Washington.

Assirey EAR (2015) Nutritional composition of fruit of 10 date palm (Phoenix dactylifera L.) cultivars grown in Saudi Arabia. J Taibah Univ Sci. 9: 75-79.
Borchani C, Besbes S, Blecker C, Masmoudi M, Baati R, Attia $H$ (2010) Chemical properties of 11 date cultivars and their corresponding fiber extracts. Afr J Biotechnol. 9: 40964105.

Bouhlali EDT, Ramchoun M, Alem C, Ghafoor K, Ennassir J, Zegzouti YF (2017) Functional composition and antioxidant activities of eight Moroccan date fruit varieties (Phoenix dactylifera L.). Journal of the Saudi Society of Agricultural Sciences. 16: 257-264.

Crisan EV, Sands A (1978) Nutritional value. 1st edn. Academic Press, New York.

El-Merghany S, El-Daen EM (2013) Evaluation of some date palm cultivars grown under toshky conditions. J Plant Production. 4: 1207-1218.

FAO (2015) Word production of dates. Food and Agriculture Organization. Available: http://faostat3.fao.org/browse/Q/QC/S

Folch J, Lees M, Stanley GHS (1957) A simple method for the isolation and purification of total lipids from animal tissues. J Biol Chem. 226: 497-509.

Galant AL, Kaufman RC, Wilson JD (2015) Glucose: Detection and analysis. Food Chem. 188: 149-160.

Ghnimi S, Umer S, Karim A, Kamal-Eldin A (2017) Date fruit (Phoenix dactylifera L.): An underutilized food seeking industrial valorization. NFS Journal. 6: 1-10.

Hall GM (1996) Methods of testing protein functionality. 1 st edn. Chapman \& Hall, London.

Kabacoff RI (2011). R in action. Data analysis and graphics with R. 2nd edn. Manning Publications, New York.

Krueger RR (2015) Date palm status and perspective in the United States. In: Al-Khayri JM, Jain SM, Johnson DV (eds) Date palm genetic resources and utilization: Volume 1: Africa and the Americas, 1st edn. Springer, New York.

Mohamed RMA, Fageer ASM, Eltayeb MM, Ahmed IAM (2014) Chemical composition, antioxidant capacity, and mineral extractability of Sudanese date palm (Phoenix dactylifera L.) fruits. Food Sci Nutr. 2: 478-489.

Mrabet A, Ferchichi A, Chaira N, Mohamed BS (2008) Physico-chemical characteristics and total quality of date palm varieties grown in the southern of Tunisia. Pak J Biol Sci. 11: 1003-1008.

Nixon RW (1928) The Direct Effect of Pollen on the Fruit on the Date Palm. J Agri Res. 36: 97-128.

Oberoi DPS, Sogi DS (2017) Utilization of watermelon pulp for lycopene extraction by response surface methodology. Food Chem. 232: 316-321.

Pratt BM (1994) The use of sensory evaluation techniques in food product development at key stages 3 and 4 of design \& technology. Paper presented at IDATER 1994 Conference, Loughborough: Loughborough University.

R Core Team (2015) R: A language and environment for statistical computing. Vienna, Austria: R Foundation for Statistical Computing. Available from https://www.rproject.org/

Ruck JA (1969) Chemical Methods for Analysis of Fruits and Vegetables. Summerland Res Stat, Dept Agri Canada. SP50. Salomon-Torres R, Ortiz-Uribe N, Villa-Angulo R, Villa-Angulo C, Norzagaray-Plasencia S, Garcia-Verdugo C (2017) Effect of pollenizers on production and fruit characteristics of date palm (Phoenix dactylifera L.) cultivar medjool in Mexico. Turk J Agric For. 41:338-347.

SIAP (2017) Anuario estadistico de la produccion agricola (Spanish).Available: 
http://infosiap.siap.gob.mx/aagricola_siap_gb/icultivo/ind ex.jsp

Shaaban, SHA, Shaaban MM (2012) Nutritional evaluation of some date palm (Phoenix dactylifera L.) cultivars grown under egyptian conditions. J Am Sci. 8: 135-139.

Steel RGD, Torrie JH (1980) Principles and procedures of statistics. 1st edn. McGraw Hill, New York.

Vinita V, Punia D (2016) Nutritional composition of fruit of four date palm (Phoenix dactylifera L.) cultivars grown in Haryana, India. Asian J Dairy Food Res. 35: 331-334.
Vinson JA, Zubik L, Bose P, Samman N, Proch, J. (2005) Dried fruits: Excellent in vitro and in vivo antioxidants. J Am Coll Nutr. 24: 44-50.

Yousif AK, Benjamin ND, Kado A, Mehi-Alddin S, Ali SM (1982) Chemical composition of four Iraqi date cultivars. Date Palm J. 1: 285-294. 